Ewa Pańkowska

Biatystok

\title{
Мир умирающей российской деревни в творчестве «новых реалистов» (на материале романов: Санькя Захара Прилепина и Елтьиевы Романа Сенчина)
}

Ключевые слова: современная российская деревня, деградация, смерть, гибель

Роман Сенчин и Захар Прилепин занимают главные позиции среди часто читаемых и обсуждаемых авторов, представляющих так называемый «новый реализм» ${ }^{1}$, который претендует быть современной формой бытования классических традиций русской литературы ${ }^{2}$ с ее психологическим антропоцентризмом, социально-политическим критицизмом и воспитательной функцией [Ротай 2013, online]. На материале произведений вышеупомянутых писателей можно выявить базовые принципы «нового реализма» ${ }^{3}$ и одновременно рассмотреть индивидуальные авторские концепции (варианты) этого явления современной

\footnotetext{
1 «Новый реализм»- это спорное явление в литературном процессе. В сложившейся полемике «новый реализм» описывается по-разному: «как новый этап развития реалистического метода или как знак деградации художественной прозы в журналистику и бытописательство, лишенное литературного вещества» [Аристов 2011, 170 , online]; как «искусственное образование, сочиненное группой критиков и малоодаренных писателей» [Липовецкий, online]; «как главный миф русской литературы 2001-2009 годов» [Беляков, online]. См. тоже: Пустовая В., 2005, Пораженцы и преображенцы. О двух актуальных взглядах на реализм, «Октябрь», № 5 .

2 Как замечает прозаик Дмитрий Новиков: «"новый реализм" - явление не новое. Это продолжение традиций всех предыдущих видов реализма, начиная с социалистического и заканчивая магическим. Хотелось бы думать, что он впитает в себя и нелегкий опыт постмодернизма, без лишней, впрочем, увлеченности формальным конструированием абстрактных смыслов, уводящих в пустыню от живой, яркой, сочной, больной, непредсказуемой жизни» [Новиков 2007, online].

$3 \mathrm{~K}$ доминирующим признакам «нового реализма» относится, например, автобиографизм как существенный метод сюжетостроения, позволяющий автору креативно
} 
российской словесности, т.е. социально-психологическую прозу Сенчина (его критический, «жесткий» реализм) и сентиментальную «пацанскую» прозу Прилепина [Беляков 2009, «Знамя», online].

По мнению Сенчина, «новый реализм» - «это предельно достоверное описание, похожее на документ. Фиксация современного состояния людей» [Ocс 2010, online]. «Предельно правдоподобная проза, которая включает в себя и натурализм» [Русаков 2013, online]. Сенчин подчеркивает:

Для меня проза делится на изящную словесность, где важны не столько содержание, герои, сюжетное развитие, а сам язык (...), и на, конечно, в художественном оформлении, на - документ. Исторический, психологический, человеческий... [Прилепин, Интервью с Романом Сенчиным, оnline].

Творческим кредо писателя можно считать следующую мысль «не скрывать под оболочкой привычную, сладковатую гниль, показать правду, чистую, без оговорок, без иллюзий, без миражей» [Сенчин 1997, online]. Прозаик действительно пытается максимально сблизить художественный текст с реальностью ${ }^{4}$, стремится к максимальному внешнему правдоподобию деталей, в своих произведениях бытовое и материальное окружение он описывает во всех подробностях. В текстах Сенчина мы не найдем динамичного действия, ярко выраженных конфликтов, так как автор просто фиксирует время, которое течет спокойно, неторопливо, однообразно. Для Сенчина художественным объектом становится просто повседневность, «бытовуха» 5 со всеми подробностями, порой шокирующими, даже отталкиваю-

использовать собственный житейский опыт, личные воспоминания [Ротай 2013, online]. Создавая своих персонажей, и Сенчин, и Прилепин ориентируются, в разной степени, на собственную биографию.

4 Следует подчеркнуть, что в ранних произведениях Сенчина автор и герой сближаются, часто совпадают в имени и ключевых событиях биографии. Писатель сознательно желает оставаться в контексте действительно происходящих событий. Своим именем, отчеством и фамилией Сенчин как будто удостоверяет подлинность, достоверность сообщаемого (напр., в трилогии с общим героем Романом Сенчиным, которую составляют: повесть Минус (2001), роман Нубук (2002), повесть Вперед и вверх на севших батарейках (2004)). При подробном исследовании трилогии Сенчина необходимо учесть рассуждения Филиппа Лежёна, крупного специалиста в области мемуарно-автобиографического жанра, и обратиться к его классическому труду: Автобиографический пакт (P. Lejeune, Le Pacte autobiographique, Paris 1975).

5 Прозаик отказывается от постановки и попытки решения философских, религиоведческих, политических вопросов [Ротай 2012, online]. 
щими ${ }^{6}$ Исследователи творчества прозаика замечают, что вся его сила как раз в этой нарочитой обыденности. Сенчин доводит привычность, обыденность бытовой человеческой жизни до крайней степени, чтобы, таким образом, показывать ее во всей чистоте бессмыслицы и несуществования [Журов 2012, online], чтобы подчеркнуть экзистенциальную пустоту, отсутствие истинного смысла в такой повседневной жизни, чтобы подчеркнуть ужас такой обыденности.

Основной целью прозаика становится отображение эмоционального состояния, сознания человека, причем Сенчину важно показать судьбу не сильной личности с четкой жизненной целью7, а человека, не отличающегося пафосом активности, человека с размытыми, невнятными ориентирами, который не в состоянии принимать решения, делать выбор, т.е. активно менять свою жизнь и положительно влиять на окружающую действительность ${ }^{8}$. Это человек, который «сбился со своей орбиты, потерял стержень» [Сенчин 2001, online]. Он без сил и энергии, чтобы действовать, «полудохлый», обессиленный, искалеченный, исповедующий философию недеяния. Жизнь для героя Сенчина просто капкан, из которого он не способен выбраться.

Подытоживая, можно утверждать, что прозаик неутомимо описывает повседневность, сохраняя при этом редкую наблюдательность и дотошное знание быта, мелочей жизни, поэтому он всегда конкретен и точен, «жесток и безжалостен, как сама жизнь» [Журов, online]. Сенчин создает более-менее объективные картины сегодняшней российской действительности, портреты типов сегодняшних людей, которым в сущности радоваться особенно нечему. Как говорит сам писатель:

6 Главный герой повести Вперед и вверx на севших батарейках констатирует: «писатель (...) - это человек, который в первую очередь видит всякие отклонения. И их фиксирует, разбирает...» [Сенчин 2004, online].

7 Уровень притязаний героев Сенчина часто снижен до минимума. K необходимому для их жизни набору относятся: сон, еда (алкоголь в большом количестве), туалет, работа, даже самая ничтожная, но все-таки с зарплатой. «Как выжить?»- вот главная цель таких персонажей, поэтому их чаще занимают физиологические аспекты существования, чем аспекты духовные. Побеждает быт, человеческая мелочность. Нет у Сенчина никакого романтического начала, никакой поэтизации ни молодости, ни таланта, никаких протестных настроений. Герой Сенчина - обыкновенный, заурядный человек, не умный и не глупый, нормальный, погруженный в повседневное течение жизни, просто такой тип «маленького человека» [Беляков 2009, «Новый мир», online].

8 Таня, одна из героинь повести Вперед и вверх на севших батарейках, для определения такого типа людей употребляет просторечное слово «чмо»: «... "чмо" - это не оскорбление, это просто такой тип людей. (...) Посмотри со стороны, как ты живешь. Как ты одет вообще, прическа какая. И ты же, в плане жизни, ни на что не способен» [Сенчин 2004, online]. 
...Я пытаюсь писать о жизни ничем особенным не выдающихся, как Пушкин их называл „ничтожных”, людей. Хотя каждый человек особенен и уникален. Но жизнь большинства складывается из череды дней-близнецов, которые не запоминаются, не радуют и не огорчают, почти не отмечаются. Настоящие события - хорошие или плохие, здесь нет существенной разницы - происходят очень редко. И вот эти бесцветные, лишние дни я и беру для описания. Пишу об этом в соответствующей тональности. (...) чтобы зафиксировать эти свои и других людей безрадостные дни, я и занимаюсь литературой [Прилепин, Интервью с Романом Сенчиным, online].

Отличительные черты прозы Сенчина - мрачность, безысходность, бессмысленность, пессимизм, жесткая реалистичность - «грубая, сермяжная правда жизни»; главная и постоянная тема - заедание человека средой, бытовое рабство, безволие, бессильная деградация, беспросветность, бесперспективность [Современнье писатели России. Библиографический указатель 2013, 17, online].

Привлекательность творчества Прилепина, в свою очередь, заключается в «крепком инстинкте жизни», в своеобразной «энергетичности».

Капитолина Кокшенева, критик и публицист, констатирует: «Проза Захара Прилепина - энергетическая. Только в отличие от тупых напитков-энергетиков, в ней доминирует настоящая сила жизни, крепко заточенная им в слово» [Захар Прилепин - Omзылвы, online].

Дмитрий Быков, писатель, поэт, публицист, замечает: «Проза Прилепина вызывает желание жить - не прозябать, а жить на всю катушку» [Захар Прилепин - Oтзыьвы, online]. Уместно здесь добавить, что именно Прилепину литературная критика приписывает создание нового социально-психологического типа - современного революционера [Костырко 2006, online], героя-действователя ${ }^{9}$, который занимается настоящим мужским делом ${ }^{10}$ (напр., войной, борьбой с социальной несправедливостью, спасением ребенка). По словам Кирилла Гликмана:

9 Здесь намечается существенная разница между героями Сенчина и Прилепина. Персонажи Сенчина, как мы уже заметили, это главным образом наблюдатели, самозамкнутые посредственные личности, бесконечно рефлектирующие, но бессильные что-либо изменить.

10 Некоторые упрекают писателя в излишне акцентируемом автобиографизме, в «авторском мужском нарциссизме», так как герои Прилепина часто обладают сходным с автором мировоззрением, жизненным опытом и даже «мужественной» внешностью (напр., Егор Ташевский, главный герой романа Патологии (2004), как-то похож на своего создателя) [Аристов 2012, 28-29, online]. 
...Прилепин-писатель (...) выводит на авансцену отечественной литературы героя, способного продолжить ряд бесстрашных и прямодушных правдоискателей, воинов, в наше безгеройное время становящегося воплощением героики как таковой [Гликман 2011, online].

Евгений Прилепин, более известный под псевдонимами Захар Прилепин и Евгений Лавлинский, не замыкается в герметичной литературной среде, он выступает также в качестве общественного деятеля, публициста, оппозиционного политика, последовательного критика власти. Многие утверждают, что именно этот универсализм Прилепина является одной из составляющих его успеха [Рудалев, Беляков 2009, online].

Литературный критик и литературовед Алла Латынина подчеркивает факт, что Прилепин вместо настоящего имени «Евгений» выбирает простонародное «Захар», которое звучит тяжело, угрюмо, но почвенно, и в этом выборе имени, по мнению Латыниной, сконцентрирована вся писательская стратегия автора [Латынина 2007, online]: позиционировать себя как человека из народа (даже борца за народные права), выделять свою тесную связь с «народной почвой», с национальным духом. Как замечает сам писатель: «Нна (литература - Е.Р.) в моем понимании истинная, потому что вслушивается в клич людей, чувствует все токи земли. Эта литература (...) дышит тем воздухом, что и народ» [Яблонская 2014, online].

Особое внимание Прилепин действительно уделяет остросоциальной и острополитической проблематике. В целом тематика его произведений разнообразна: нравственное здоровье современного человека (внутренний кризис и депрессия), взаимодействие личности с окружающей средой, семейная жизнь: угасание любви и распад семьи, патриотизм, жестокость и насилие, сохранение человечности в нечеловеческих условиях войны (будни чеченской войны).

Материалом исследования в настоящей статье послужили два романа: Санькя (2006) Прилепина и Елтылшевь (2009) Сенчина, произведения, несомненно, значимые в рамках «нового реализма», значимые для самих писателей, для их творческого развития, уместно здесь также добавить, что появление этих книг стало заметным событием на российской литературной сцене ${ }^{11}$. В статье мы сосредоточим внимание

11 В 2006 году роман Санькя вышел в финал премии «Национальный бестселлер», в том же году Прилепин получил за этот роман диплом премии «Эврика». В 2007 году роман вышел в финал премии «Русский Букер», в том же году Прилепин получил пре- 
на теме деградации российской деревни сегодняшнего дня. Деревенская реальность, описанная в обоих романах, мрачная и безнадежная ${ }^{12}$. Диагноз, поставленный писателями, однозначен: деревня, которая всегда считалась оплотом традиции, ментальности русского народа, «источником жизни», который питал Россию, постепенно умирает, и, к сожалению, шансов на ее возрождение пока нет ${ }^{13}$. Как комментирует Прилепин (писатель родом из деревни Ильинка Рязанской области, его семья в настоящее время живет в деревне Ярки):

...возрождение русской деревни невозможно ${ }^{14}$. Либо это должен быть большой общегосударственный рывок, когда будет создана такая благостная модель жизни в деревне, когда там появятся рабочие места. Это в ближайшее время не произойдет, т.к. это не рентабельно, а уж тем более этому государству, которое ворует. Любой другой власти это будет невыгодно, т.к. будет нужно поднимать промышленность, военную сферу, космос, нанотехнологии [Муравьев, online].

Сенчин, в свою очередь, констатирует, что упадок деревни происходил постепенно, и, по его мнению, это город убил деревню:

...Сначала из русской деревни всячески выбивали крестьянский дух, когда люди могли сами себя содержать, работать на себя, обогащаться. Издавна крестьян всячески гнобили. В советское время деревня стала зависеть от города во всем. Хлеб в деревню теперь завозят повсеместно. Если сейчас деревню оставить на месяц без автолавок, без городской помощи, то

мию «Ясная Поляна», с формулировкой «За выдающееся произведение современной литературы - роман Санькя». В 2007 году роману Санькя была присуждена также всекитайская литературная премия «Лучший зарубежный роман года». В 2009 году роман Eлтьишевы вошел в шорт-листы главных литературных премий России «Большая книга», «Русский Букер», «Ясная Поляна», «Национальный бестселлер»и стал одним из самых обсуждаемых в литературной прессе произведений; в 2011 году роман вошел в шорт-лист премии «Русский Букер десятилетия».

12 Жестокость и правдивость изображения деревенских реалий напоминают произведения Антона Чехова Мужики (1897) и В овраге (1900), повесть Ивана Бунина Деревня (1910).

13 По статистическим данным, например, с 1990 по 2010 год в России количество населенных пунктов сократилось на 23 тысячи. Бо̀льшую часть исчезнувших населенных пунктов - до 20 тысяч - составляют села и деревни. Еще 20 тысяч оказалось на грани вымирания. В целом, русская деревня пребывает в состоянии глубокой депрессии, наблюдаются массовый уход молодежи в города, пьянство и алкоголизация населения [См. напр.: Калинин, online; Слепаков 2012, online].

14 Одновременно Прилепин обращает внимание на факт, что огромное количество горожан начинает мигрировать в сторону сельских мест. Писатель понимает, что деревни в том виде, который она имела еще в эпоху его детства, уже не будет. Он вполне осознает невозвратную утрату прошлого, но надеется, что в деревенских пространствах хотя бы кто-то будет жить [Муравьев, online]. 
большинство жителей через месяц умрет с голоду. Там получают пенсии и идут в магазин. Даже картошку не все выращивают [Occ, online].

Санькя - роман о членах экстремистской, левонационалистической организации «Союз созидающих ${ }^{15}$. Эти современные революционеры обладают разрушительной, по существу, идеологией ${ }^{16}$, которая сводится к стихийному бунту против власти, к борьбе с враждебной, по мнению «союзников», существующей государственной системой. У «союзников» одно стремление - погибнуть, унеся с собой в могилу хотя бы часть современного мира, лживого и отвратительного [Басинский 2006 , online]. Можно сказать, что в сущности, мы имеем дело со стихийным анархизмом, очень радикальным и очень наивным [Беляков 2006, online].

В анализируемом произведении Прилепин, конечно, выходит за пределы основной темы о революционном бунте в России и значительно углубляет проблематику, развивая ее до уровня философско-символических обобщений, относящихся, главным образом, к вопросу национальной идентичности, национального самосознания. В этом контексте очень важной в романе является «деревенская» сюжетная линия [Славина 2012, 63, 64]. В национальной картине мира Прилепина именно деревня занимает особое место, деревня как основа национального менталитета, основа русской духовности. Формирование личности Александра Тишина, главного героя романа, формирование его национального чувства - любви к родине происходило под влиянием бабушки и дедушки, живущих в деревне. Само название произведения уже указывает на эту связь: именно деревенские родственники называли Сашу по-простонародному «Санькя» [Прохорова 2013, 196, online]. Сам Прилепин уверяет, что деревню Ярки - место своего жительства, он всегда предпочтет и Европе, и Москве. Писатель подчеркивает:

...Я рос в деревне, где люди жили веками. У меня все предки крестьяне, они там жили (...), ходили в лаптях, спали на печах. Все это было для меня совершенно органичным образом. (...) Природа, река, лес, простор,

15 Следует отметить, что Прилепин с 1996 года член Национал-большевистской партии (запрещенная в 2007 году решением суда как экстремистская организация), сторонник коалиции «Другая Россия» (оппозиционное общественное объединение в России, действовавшее с 2006 года по 2010 год). Можно считать, что прототипом для «Союза созидающих» послужила именно Национал-большевистская партия.

16 У «союзников» нет никакого, даже самого приблизительного, самого утопического, плана на будущее [Беляков 2006, online]. 
березка и рябинка что-то накладывает на психику человека. (...) Город нивелирует ощущение Родины. (...) А вот природное и речевое пространство формирует в человеке патриотизм [Муравьев, online].

Эти высказывания вполне подтвреждают, что для Прилепина характерно очень положительное отношение к естественному, к простому, к понятному, к народному. В связи с этим можно предполагать, что в анализируемом романе писатель пытается противопоставить две среды: город и деревню как искусственное и естественное ${ }^{17}$. Город выступает как место по самой своей сути искусственное, при этом омерзительное, враждебное, искажающее все, до чего сможет дотянуться ${ }^{18}$, как место, внутри которого одна лишь пустота [Штейнбах, online]. K сожалению, в современной деревне, как выразительно показывает Прилепин, также почти уже не осталось ничего положительного, доброго, светлого: наоборот, здесь глухо, тоскливо, страшно, везде царствует запустение, деревенский уклад медленно, но неминуемо гибнет. Неудивительно, что сюжет возвращения Саши в родные места окрашен в тоскливые и мрачные тона. Кажется, что в деревне всегда были и будут только грязь, холод, непроезжие дороги [Прохорова, 197, online]. Возвращаясь в свой родительский дом, Санькя не чувствует оживления, ему сопутствует чувство безнадежности ${ }^{19}$, так как деревня предстает пространством беды:

Ему (Саше - Е.Р.) давно уже казалось, что возвращаясь в деревню, сложно проникнуться какой-либо радостью - настолько уныло и тошно было представавшее взгляду. (...)

Улица была пустынна, темна и грязна, как и все остальные улицы деревни. (...)

17 Таким образом, в Саньке намечается своеобразная связь с традицией деревенской прозы второй половины XX века. Как известно, «деревенщики» позиционировали себя в качестве защитников традиционных нравственных ценностей, хранительницей которых для них была деревня, противопоставленная развратному, порочному, бездуховному городу [Иванова 2013, 89, online]. Уместно здесь добавить, что в эссе Ваше императорское величество (2009) Прилепин сказал о себе: «я, последний писатель деревни» [Прилепин 2009, online].

18 «Все равно в этом мерзком городе, который всегда был противен Саше, отца хоронить было нельзя» [Прилепин 2006, online]. Можно утверждать, что в Саньке город выступает как символ пошлого обшества потребления с его социальным расслоением. 19 Надо подчеркнуть, что на протяжении всего романа герой не переживает даже мимолетного ощущения счастья. Он бежит из города, которого ненавидит, в деревню, где, в свою очередь, одни беспросветность и вездесущий «запах» смерти. Санькя испытывает то отвращение, то усталость. 
Деревня исчезала и отмирала - это чувствовалось во всем. Она отчалила изрытой, черствой, темной льдиной и тихо плыла. Заброшенные, вросшие в землю сараи, стоявшие вдоль дороги, чернели отсыревшими боками, прогнившими досками. На крышах сараев росла трава и даже кривились хилые деревца, прижившиеся, но не нашедшие куда пустить корни - под их слабыми корешками располагались холодные, опустевшие помещения, куда, к разбитым крынкам и продырявленным бочкам, заползали ужи, которых никто уже не тревожил. Кусты разрослись и ползли на дорогу.

Среди всего этого медленного и почти завершившегося распада ребенок смотрелся странно, стыдно, неуместно [Прилепин 2006, online].

Прилепин с горечью изображает ветхость, убожество, деградацию русской деревни и постепенное угасание ее жителей: старожилы умирают, а молодого поколения просто в деревне нет ${ }^{20}$. Остались лишь единицы людей, покинутых и несчастных, не понимающих и даже уже не замечающих друг друга, в их душах вместо любви, надежды, добра живут одиночество, ощущение безысходности [Славина, 64]. Складывается впечатление, что жизнь деревенских жителей это даже не круговорот, а необратимая дорога к смерти, они как будто устали жить и ждут смерти [Николаев, Воробьева 2013, online]. Все вокруг кажется мертвым, уходящим.

В соседней комнате умирал дедушка. (...)

В крайнем по улице доме жил мужик по прозвищу Хомут. Саша хорошо знал его. (...) Прошлым летом он удавился. K нему приехали из города сыновья, помочь с огородом. Работая на огороде, Хомут с сыновьями разругался. (...) Разругался и сказал: «Сейчас я вам покажу!». Ушел в дом. Сыновья махнули рукой и продолжили работу. Когда пришли, обнаружили отца в сарайке - повесился на перекладине, ноги подогнув. Нет теперь Хомута.

Через двор от родного Сашиного дома вместе со своей матерью жил мужик по прозвищу Комиссар. (...) Сначала померла его тихая матушка, а вскоре и сам он умер, что-то с сердцем [Прилепин 2006, online].

Бабушка Саши еще жива, но живет она больше по инерции - доживает и все время говорит только об одном - о том, что все ее близкие умерли, и больше уже ничего нет. Можно сказать, что в деревне вообще почти нет никаких «признаков жизни».

20 Молодое поколение абсолютно не пересекается с прежней жизнью. Санькя тоже давно чужд сельскому миру. 
...Дальше располагалось стойло, где бабушка уже год как не держала козу, три года как там не было свиней, и десять лет как оттуда увели в последнюю дорожку корову Доманьку. Из стойла не доносилось запахов жизни, навоза, ни одна мохнатая душа не переступала там копытцами, никто не жевал, шумно дыша и пугаясь Сашиных шагов. Пахло только сыростью и грязью [Прилепин 2006, online].

Одним из самых сильных эпизодов романа Санькя является история похорон отца главного героя, когда три человека - женщина (мать Саши), мужчина (Безлетов, бывший ученик отца Саньки) и подросток (Саша) больше десяти часов волокут гроб через снежную пустыню, так как автобус не смог проехать к деревне ${ }^{21}$. Как справедливо замечает Ольга Лебёдушкина: «деревня (...) зовет, но не слишком пускает - ни живых, ни мертвых. Бездорожье, окружающее ее почти круглый год, приобретает в романе почти мистический космический смысл» [Лебёдушкина 2006, online].

Они минули городок (...), и спустя семь минут по обе стороны шоссе открылась равнина.

Вид белого, до горизонта поля, был тягостен. Эта даль и пустота (...) засасывала.

- Безлюдье... - шептал Саша тихо. - На безлюдье льды... Снеги и льды... (...)

Они взялись за верх гроба, вытаскивая его, но мать не выдержала и, охнув, уронила свой край. Саша и Безлетов тоже (...) не удержали. Гроб упал набок.

Незабитая крышка вскрылась, отец (...) едва не выпал в снег. (...) Но в то малое мгновенье, когда гроб стоял на боку, картина была страшна - мертвый профиль отца, выпавшая в снег иконка с груди, недвижимые, белые руки, открывшиеся под покрывалом... (...)

- Настоящие русские похороны... - неожиданно сказал Безлетов (...), русские проводы (...) [Прилепин 2006, online].

Несомненно, события, происходящие в этом эпизоде, символичны. Можно утверждать, что гроб с телом отца символизирует все, что в России имеется и что от России осталось [Наринская 2006, online]: как будто печать смерти лежит на всем и на всех в России. Изображая гибель деревни, Прилепин в очень яркой и убедительной форме пытается передать мысль о нравственном оскудении, тотальном разложении

21 Эта невозможность возврата в родную деревню приобретает в романе символическое значение: между деревней и городом - огромный, непреодолимый провал [Богатырева 2014, 9, online]. 
и в конечном итоге вымирании народа в целом. Для писателя смерть провинциальной деревни означает утрату связи с родной землей, со своими народными корнями, предками, традициями, с национальным духовным целым (означает разрушение национальных основ), утрату национальной идентичности - беспочвенность, безопорность, потерю родины - России, вместо которой остается лишь пустота, носящая ее имя. Вот почему главный герой романа Санькя говорит, что у него родину просто отняли [Пустовая 2009, «Континент», online]. По нашему мнению, Прилепина вполне можно назвать защитником и современным проповедником тезиса, что все корни русской души именно в крестьянстве. Таким образом, деревня остается для писателя символом света и святости, источником настоящих ценностей. Следует здесь добавить, что носителем «высшей истины» Прилепин сделал в произведении деревенского старика. Этот деревенский «мудрец-пророк» ${ }^{22}$ рассуждает о трагедии сегодняшнего дня, о людской деградации (утрате нравственных ориентиров) и неизбежном возмездии за греховные деяния людей:

...Я все жду, когда вы все побежите в деревню, всем народом городским: близится срок-то. (...) И говорю вам: скоро побежите все, как поймете, что от вас устали. Но бежать будет некуда: все умерли, кто мог приютить. В сердцах ваших все умерли, и приюта не будет никому... (...)

...Вы там в церкву, говорят, все ходите. Думаете, что, натоптав следов до храма, покроете пустоту в сердце. Люди надеются, что Бога приручили, свечек ему наставив. Думают, обманули его. (...) И печаль не о том, что ничтожен человек, а то, что он зол в своем ничтожестве. Чем больше замечает, что другие его ничтожество видят, тем злее становится... Нету выхода вам больше, так [Прилепин 2006, online].

Подытоживая, можно отметить, что в Саньке Прилепин показывает «огромную пустоту», «безжизненность» современной деревни и од-

22 Тип героя-праведника (воплощение национально-традиционных ценностей) входит в русскую классическую литературу во второй половине XIX века, появляется в творчестве Ивана Тургенева, Николая Лескова, Федора Достоевского, Льва Толстого, Антона Чехова и других писателей. K этому типу тяготеют и хранители «деревенского мира» - герои-праведники «деревенской прозы» XX века, которых можно считать одним из художественных вариантов более широкого литературного архетипа - «мудрого старца (старухи)» [Королева 2009, 79, 80, online]. Следует здесь, например, упомянуть о Матрене-праведнице, героине рассказа Александра Солженицына Матренин двор (1963, первоначальное авторское название Hе cmoum cело без праведника), или о «мудрых старухах» Валентина Распутина: Анне (Последний срок, 1970), Дарье (Прошание с Матерой, 1976), Агафье (Изба, 1999). 
новременно стремится доказать важность ее сохранения для самосознания русского народа. Как утверждает писатель:

...деревня - это не просто ряд домов в сельской местности, (...), это определенный уклад жизни, это речь, (..), это язык, на котором мы сейчас разговариваем, он весь вышел из деревни. Наша словесность - это и есть наше миропонимание. Вместе с деревней мы отрубаем огромный пласт своей жизни, своего сознания, своей души, потому что мы больше не будем знать этого языка. Всех вещей, связанных с крестьянским трудом. Этих мифов и сказок. Этих притч... [Ахмедова 2013, online].

Прилепинское понимание национального неразрывно связано с осознанием своих корней, земля, почва - это концепты, очень важные для прилепинского художественного мира.

В романе Eлтьлшевьл найдем довольно полный набор типичных сенчинских приемов, персонажей, мотивов и ситуаций. Писатель в очередной раз погружает читателя в серую обыденность, снова поражает точностью в описании деталей, достоверностью изображения картин быта и нравов, снова проявляет уникальную наблюдательность над внутренними качествами современного российского человека.

На фоне вымирающей деревни (общей безнравственности, поджогов, убийств, алкоголизации населения) Сенчин показывает постепенную деградацию, угасание и окончательное падение, гибель среднестатистической российской семьи, члены которой не в состоянии противостоять собственному уничтожению.

Родоначальник, капитан милиции Николай Михайлович Елтышев, дежурный по вытрезвителю, из-за служебного преступления теряет работу и ведомственную квартиру в районном городке. Это событие обрывает налаженную инерцию будней - семья Елтышевых вынуждена переселиться в зауральскую деревню Мураново ${ }^{23}$, где осталась родственница Валентины Викторовны, жены Николая Михайловича.

23 В романе Eлтылевь Сенчин использует собственные наблюдения, личные ощущения горожанина, поселившегося в деревне. Одновременно писатель старается все больше опираться на жизнь социальную, от самонаблюдения и «эгоцентризма» автопсихологической прозы переходит к «объективному» письму. Как сам подчеркивает: «До «Елтышевых» я написал множество рассказов и повестей о горожанах, которые оказываются в деревне и вынуждены там жить: «Минус», «Нубук», «Перед снегом». (...) Может быть, «Елтышевы» стали итоговой вещью об этом, а может, и нет. Четыре года, прожитых в деревне, дали мне богатый и страшный материал, меня очень изменили. Невозможно прекратить вспоминать о той жизни, тем более, что, приезжая к родителям, я на месяц-полтора в нее погружаюсь...» [Сафронова 2010, online]. 
Именно Валентине деревенская жизнь в глубине души представляется «как нечто светлое, единственно правильное», деревня, ее малая родина, обещает как будто выход. Но переезд в тесную деревенскую избушку тетки-старухи, как можно предполагать, не означает перемены к лучшему 24 : вернуться к корням и начать новую счастливую жизнь среди колосящихся хлебов, выращенных своими мозолистыми руками, не удается [Бабицкая, online]. Семейство горожан попадает в «настоящий деревенский ад», а в конечном итоге Елтышевы обнаруживают себя на «беспросветно черном дне ямы» этой деревенской жизни [Пустовая 2009, «Новый мир», online]. В Муранове царствуют нищета, безработица ${ }^{25}$ и смерть ${ }^{26}$ - жители «мрут, мрут и мрут» от убийств и самоубийств, пьют не просыхая - от безделья и безысходности, сельским хозяйством, в принципе, никто не занимается, люди торгуют спиртом или воруют, в том числе друг у друга. Как справедливо замечает Ирина Роднянская, деревня Мураново «крайне депрессивна»: это место без дорог, без удобств, без лекарств. Сенчин создал абсолютно реальную, честную картину российской деревни «нулевых» 27 (начала 2000-х) [Роднянская 2010, online].

...Когда-то это было село - на холмике стояла церковь, которую в шестидесятых снесли и поставили на ее месте похожий на амбар клуб. Главной

24 «...теткина изба вызывала (...) нечто похожее на ужас. Ужас перед тем, как перезимуют в ней, сколько предстоит сделать за лето, чтобы следующую зиму встретить в более-менее человеческих условиях» [Сенчин 2009, online].

25 «У меня местные без работы. И мужики, и все. Скотники, механики, доярки, трактористы, повара... В том году ферма еще была, а теперь - ничего. Вообще ничего» [Сенчин 2009, online].

26 К смерти своих близких жители деревни относятся с полным равнодушием: «Елтышева удивило поведение окружающих - стояли и смотрели на труп как на что-то обычное. И даже Людмила, для которой теперь, со смертью мужа (...), ломалась вся ее и ее детей судьба, не рыдала, (...), а, как и другие, стояла и смотрела. Дети тоже были тут, и тоже спокойны...» [Сенчин 2009, online].

27 Литературный критик Михаил Бойко, в свою очередь, считает: «Сенчин (...) полагает, что он реалист и что сила его в предельно честном изображении жизни людей, задавленных бытом и страхом маргинализации. Ничего подобного. Сенчин изображает не реальность, а свою весьма специфическую субдепрессию, и его творчество попытка выявить объективные причины этого непреходящего и крайне угнетающего состояния» [Бойко 2008, online]. Как констатирует Алиса Ганиева (прозаик, литературный критик), на негативные стороны заоконной действительности, несомненно, в некоторой степени накладывается еще и пессимистическая оптика Сенчина, поэтому: «Зашкаливающая черная правда жизни совершенно неожиданно оборачивается страшной сказкой, хоррором (...). Среднестатистическая российская деревня Мураново с ее обилием мертвяков, с ее заколоченными домишками, горящими зданиями, грязными дорогами, жителями, потерявшими человеческий облик, и мутным небом напоминает царство ужаса» [Ганиева 2010, online]. 
улицей в Муранове была дорога в дальнюю деревню Тигрицкое. Дорога была асфальтовой, но асфальт давно разбила совхозная техника, и его не ремонтировали. (...) в самом центре деревни (...) контора с почтой, (...) магазины, из которых работал только один, остальные же два наглухо, с давних пор, заперты [Сенчин 2009, online].

Можно сказать, что Елтышевы в деревне не бездействуют: они начинают строить новый дом, трудятся на огороде, начинают торговать на базаре, не голодают, но все-таки на новом месте не осваиваются («Крестьянами они так и не стали»). Оказывается, что в сорока километрах от города начинается совершенно другая реальность: здесь каждый день как тяжелое испытание, здесь нет привычных удобств, самые простые действия отнимают очень много времени ${ }^{28}$, например, приготовление еды, мытье посуды, баня превращаются в серьезные задачи, на решение которых уходит почти весь день [Иванова, 92, online].

Постоянно возникали трудности - то, что в квартирном быту делалось почти незаметно, здесь разрасталось до серьезной, почти непреодолимой проблемы... Главной была вода.

Вода бралась из колонки. Колонка находилась рядом - на другой стороне улицы, но давление было слабым, (...) и чтобы наполнить ведро, приходилось тратить минут семь. (...)

Мытье посуды было целым процессом. Мыли ее в большой металлической чашке сначала в одной воде, горячей, затем мыли саму чашку, стенки которой были покрыты слоем жира, затем наливали в нее воду теплую (...). Эту вторую воду приходилось менять раза два, так как она опять быстро становилась жирной, и «Фейри» не помогало. Особенно тяжело было мыть после говядины... [Сенчин 2009, online].

Елтышевы напрасно пытаются как-то выжить в недоступном пониманию «городских» и жестоком, враждебном в отношении к ним деревенском мире:

...враждебны люди, даже если внешне проявляют радушие, враждебна природа, даже если она как будто благодатна.

Изобилие ягод и грибов летом означает тяжелый труд, чередование ливней и жары трудно переносить, мороз мучает бесснежную землю, а то

28 У главного героя повести Нубук сходные ощущения: «... у меня была другая жизнь. Совсем другая. В квартире на пятом этаже, с ванной и унитазом, с удобной газовой плитой, телефоном (...). теперь я жил (...) в маленькой, одичавшей деревушке, в трехоконном домике; каждый день я должен был заботиться о пропитании, ковыряясь но огороде и ухаживая за животиной (...)» [Сенчин 2002, online]. 
вдруг, наоборот, снегом завалит всю деревню до крыш, освежающий ветер становится пронизывающим. Если небо над головой ясное и высокое, то, кажется, лишь для того, чтобы дразнить невозможностью счастья или хотя бы удачи, а так оно чаще или коричнево-серое, или завалено облаками, или полно серой хмари, или оттуда светит палящее солнце [Маркова 2010, online].

Наладить крепкий деревенский быт и жизнеспособное хозяйство у Елтышевых никак не получается. Постройка нового дома затягивается и требует вложения огромных денег, но прежде всего сил и энергии, которых не хватает. Как в таких условиях существовать и при этом оставаться человеком? Старенькой тетке Татьяне, представительнице еще прежнего деревенского мира, не разгромленного неблагоприятными экономико-политическими изменениями, не развращенного, это вполне удается. Она одна управляется с хозяйством:

...иногда, казалось, что не выдержат, задохнутся в этом домике-склепе, перегрызут друг друга - теснота порождала ссоры, обостряла раздражение. Но - все-таки как-то переживали. Помогала тетка Татьяна. (...)

...ее медленное, но упорное, каждое утро продолжающееся существование заставляло и Елтышевых вставать с кроватей, умываться, что-то делать. (...)

...Картошки и солений у тетки Татьяны было запасено прилично - даже не верилось, что она, еле передвигающаяся, нарубила целую кадку капусты, насолила с полсотни банок огурцов и помидоров, спустила в подпол картошку, морковку редьку, свеклу, бруснику засахарила, варенья наварила. И никто ей, говорила, не помогал, единственная помощь - огород по весне трактором вспахивали [Сенчин 2009, online].

Такой стойкости (серьезного духовного стержня), способности к сверхнапряжениям, пассионарности, но самое главное, воли к жизни у Елтышевых, как и у многих других жителей деревни Мураново, просто нет:

Николай Михайлович стал перебирать в уме деревенских мужиков. За полгода он успел ко многим присмотреться и поделил их на две части. Бо̀льшая - существующие кое-как, в убогих избенках, вечно полупьяные, проводящие дни или на скамейках возле калиток, будто немощное старичье, или, с приходом тепла, на берегу пруда, над которым зависли жутковатые остатки сгоревшего заводика... [Сенчин 2009, online].

В борьбе за выживание Елтышевы, к сожалению, забывают о собственном достоинстве, теряют человеческий облик. Они просто любыми способами стараются поддерживать свое существование - превра- 
щаются в спекулянтов 29 , а даже в преступников. Оказавшись в «лачуге в одичавшей, гибнущей деревне», без помощи, без сочувствия, Елтышевы горе заглушают алкоголем:

В эту зиму много пили. Как-то автоматически, как давно болеющий принимает лекарство через определенный промежуток времени, подходили к буфету, доставали бутылку, наливали граммов семьдесят, проглатывали. На пятнадцать-двадцать минут становилось легче пережидать мертвое время зимы, а потом глотали еще. Постепенно хмелели, дремали, что-то ели из холодильника, снова проглатывали стопочку... [Сенчин 2009, online].

Постепенно их душами овладевают злоба, отчаяние, а затем - сначала усталость, потом - равнодушие и апатия ${ }^{30}$ :

Елтышев слушал рассказы об убийствах и самоубийстве, наблюдал, как полыхает клуб на той стороне улицы, почти равнодушно. Конечно, во время пожара опасался за свой домишко, а погибших молодых еще людей не жалел [Сенчин 2009, online].

Елтышевых история с колонками, конечно, мало волновала. Не до того было. Вообще не до чего... Спасались спиртом. Не допивались до бесчувствия, но и не давали себе протрезветь [Сенчин 2009, online].

Как справедливо замечает литературный критик Лев Пирогов: «Необходимость жить дальше и есть главнейшая ёлтышевская неприятность» [Пирогов 2009, online]. Елтышевы не в состоянии выбраться из «деревенского капкана» 31 - Мураново, словно сказочное чудовище, «пожирает» очередных членов семьи: сначала обоих сыновей, потом и их родителей. Но Сенчин не возлагает вину целиком и полностью на «пьющую» и «деградированную», «плохую» деревню [Иванова, 92, online]. Ответственность несут и сами Елтышевы - ведь их жизнь уже в городе была вялой, почти лишенной смысла. Писатель наглядно показывает абсурд такого существования, устремленного лишь к бытовому

29 Валентина Викторовна, которую можно бы назвать носительницей и защитницей фамильного достоинства Елтышевых [Роднянская, online], в конечном итоге сдается: она соглашается торговать спиртом и тем самым участвовать в спаивании деревни. 30 Елтышевы от трудностей и забот бегут в дремоту, выбирают сон души как форму прижизненной смерти. Алкоголь становится для них способом самозабвения [Пустовая 2009, «Новый мир», online].

31 Ключевая характеристика художественного мира Eлтыщевыx - это замкнутость (изолированность): замкнутость вытрезвителя, в котором работал Николай Михайлович, замкнутость маленькой деревушки, и наконец, замкнутость каждого из героев в себе самом [Комаров 2011, online]. 
комфорту ${ }^{32}$, но, по сути, устремленного к ничто ${ }^{33}$. Кроме того, в характере героев выделяется безволие. С одной стороны, они хотели бы что-то изменить, куда-то вырваться, но с другой - не решаются действовать $^{34}$, поэтому их мир - это всегда мир упущенных возможностей [Маркова, online]. Необходимо добавить, что Сенчин все-таки не ставит перед собой цель обличать или спасать: он не обвиняет Елтышевых, но и не выражает особого сочувствия. Писатель просто пытается зафиксировать определенные приметы времени, определенные проблемы, указать на факторы, обстоятельства, которые могли способствовать «угасанию» и падению семейства Елтышевых.

Глава семьи Николай Михайлович ${ }^{35}$, опытный, уставший от жизни милиционер ${ }^{36}$, живет больше по инерции ${ }^{37}:$ «Нн не имел особенных увлечений, жил как-то все по обязанности, а не для души» [Сенчин 2009, online]. Елтышев-старший вполне отдает себе отчет в том, что ничего в жизни не добился (в материальном плане ${ }^{38}$, тем более в духовном), поэтому он и начинает ощущать бессмысленность будней. Одновременно в нем нарастает раздражение на такую однообразную жизнь:

Постепенно росло, обострялось раздражение. Раздражала съежившаяся от вещей и выросших сыновей, располневшей жены квартира; раздражало гудение газовой колонки, которой когда-то, после житья в бараке, так радовались; раздражала служба, однообразная, отупляющая, несмотря на все усилия, не приносящая нормальных денег; раздражали дорогие машины на улицах, нарядные витрины, пестрые людские ручьи на тротуарах [Сенчин 2009, online].

32 «..до поры до времени жизнь текла пусть непросто, но в целом правильно, как должно. Вместо черно-белого „Рекорда” появился сначала цветной „Рубин”, а потом „Самсунг”, вместо громоздкого фанерного серванта - высокая изящная вместительная стенка» [Сенчин 2009, online].

33 Здесь уместно процитировать слова Л. Пирогова: «Воли к жизни нет, потому что её подменило стремление к благополучию, а ради благополучия не сделаешь того, что сделал бы ради самой жизни. В результате стремления «жить лучше» не хватает даже для того, чтобы просто жить» [Пирогов, online].

34 «Импульс пробуждения», к сожалению, не достигает сердец Елтышевых [Пустовая 2009, «Новый мир», online].

35 Образ главы семьи воссоздан в романе наиболее детально.

36 Елтышева-старшего можно назвать «декадентом с советской основой, советским наследием».

37 Николай Михайлович даже не заметил, когда «рядом оказалось привычное, необходимое, но неинтересное существо. ЖКена» [Сенчин 2009, online].

38 Елтышев упустил шанс на скорое обогащение и успех: в 90-е «..ему предлагали увольняться со службы, “заняться делом" (...). Но он не решался» [Сенчин 2009, online]. 
«Новая» деревенская жизнь только усугубляет внутренний конфликт Николая Михайловича.

...в своей жизни, в жизни своей семьи (...) все сильнее ощущал он (...) бессмысленность и напрасность. Конечно, было что-то, наклевывались вроде удачи, возникали просветы, но тьма постепенно и настойчиво сгущалась все плотнее. Надежда сменялась злобой и тоской. Почти уже беспрерывными [Сенчин 2009, online].

Озабоченность мельчайшими подробностями быта, озлобление от бесконечных проблем, постоянных неудач ведут к тому, что бывший милиционер начинает сеять смерть ${ }^{39}$ - последовательно совершает три убийства, причем преступление в данных условиях в глазах сенчинского героя - не преступление ${ }^{40}$, а единственно возможный выход [Погорелая 2009, online]. Николай Михайлович просто сосредоточился на том, чтобы убирать препятствия: сначала избавляется от тетки, занимающей необходимую ему и жене жилплощадь, потом убивает соседа, который не хочет возвращать долг, а в итоге становится убийцей собственного «недоделанного», вечно усталого, вялого сына. Человеческое правосудие не карает Николая Михайловича ${ }^{41}$, ибо такового в деревне нет, отсутствует здесь и милосердие, и любовь к ближнему [Роднянская, online]. В Муранове жизнь подчинена примитивным инстинктам и уходит только на то, чтобы продлиться, поэтому здесь люди не помогают друг другу - наоборот, они вооружились друг против друга (непонятно, кто здесь является жертвой, а кто преступником). Жители деревни чужды нравственности, они равнодушны почти до неодушевленности. Сенчин показывает, как быстро в таком искаженном мире ненормальность становится нормой. Писатель подчеркивает хруп-

39 Здесь уместно подчеркнуть, что внешний сюжет скатывания семейства Елтышевых в пропасть постоянно коррелирует с внутренними сюжетными линиями, такими, как нарастание раздражения, злобы и ощущения безысходности в душе Елтышева-старшего [Комаров, online].

40 Можно сказать, что это бесчеловечные обстоятельства приводят Елтышева-старшего к озверению, что нечеловеческие условия понуждают выказать свою животную сущность [Погорелая, online]. Одновременно необходимо помнить, что Николай Михайлович уже раньше нарушал закон - злоупотреблял «милицейской властью». Однако он никогда не считал себя аморальным человеком, наоборот - порядочным. Как правильно замечает И. Роднянская, 70-е - это «время, сформировавшее капитана милиции и привившее ему такие (...) профессиональные обычаи. Ниточка социальной аномии, беззакония тянется с отдаленных времен как «дело житейское»» [Роднянская, online].

41 Сенчин затрагивает проблему вины и наказания, греха и раскаяния. 
кость, неустойчивость добра в таком искаженном мире, объективную слабость добра перед злом [Комаров, online].

Центральное место в романе Eлтылиевь занимает, конечно, не деревня, а люди. На первом плане располагается и требует к себе внимания сознание гибнущего человека. В анализируемом произведении Сенчин безжалостно диагностировал мрак современной российской деревни и, по мнению многих, упадок нации в целом ${ }^{42}$. Писатель показал деревню в депрессивном состоянии, брошенную, не нашедшую для себя места в современной российской действительности. Прозаик описал судьбу людей, которым не удалось влиться в абсолютно новую систему «постперестроечного периода»43 («эпохи перемен»), указал духовную беззащитность среднего гражданина страны перед требованиями «нового времени», его нравственную безоружность перед бедой. Такие граждане потеряли веру в торжество справедливости, в честность, но прежде всего в собственные силы, и кроме инстинктивного стремления выжить у них ничего не осталось: ни цели, ни смысла, ни надежды [Беляков 2011, online]. Подытоживая можно сказать, что жители деревни Мураново (средние граждане страны) пребывают в состоянии своеобразного оцепенения-спячки, они просто ждут конца своего жалкого существования. Этот вывод вполне подтверждается следующими цитатами:

Валентина Викторовна Елтышева (...). Живет одна, ни с кем не разговаривает, но целыми днями сидит у калитки на обрезке бруса. (...)

Как она переживает долгие, пустые дни, о чем думает, ради чего вообще живет, кажется, никого не интересует. Да и без нее много в деревне таких же одиноких старух. Некоторые по возрасту вроде бы и не совсем старухи еще, но образ жизни у них старушечий. Сидят у калиток, смотрят перед собой, то ли вспоминают прошлое, то ли просто ждут конца [Сенчин 2009, online].

...деревня все та же - сонная, бедная, словно бы готовая вот-вот превратиться в горки трухи, исчезнуть, но каким-то чудом продолжающая существовать [Сенчин 2009, online].

Образ гибели семейства и образ физической и моральной деградации деревни гармонично сочетаются друг с другом, поддерживают

42 «емейство Ёлтышевых - метафора национального упадка»[ Пирогов, online].

43 В одном из интервью Сенчин объяснил: «Если говорить о деревне, то мне совершенно очевидно, что она разрушена, бесхозна, населена пенсионерами, инвалидами, деклассированными элементами. (...) А к середине 2000-х я убедился в полной безысходности положения деревни» [Бабаян, online]. 
друг друга, сливаются в романе в одну цельную картину человеческого тупика. Произведение заканчивается страшными словами: «Помочь ей было некому», относящимися не только к печальной участи Валентины Елтышевой. Российской деревне, а в более широком плане и нестоличной России, тоже пока некому помочь. Как констатирует Сенчин:

...большинство деревень на грани вымирания. Вообще очень многое разрушено, и рушили не только в последние десятилетия, а веками. Поэтому как восстанавливать деревенский мир - непонятно. Может быть, и не нужно. Такая точка зрения тоже существует и не кажется дикой [Сафронова 2010, online].

В анализируемых в настоящей статье романах изображена разоренная «агрессивной современностью» деревня, причем и Прилепин, и Сенчин пытаются обратить внимание на причины гибели деревни, т.е. на гибельность социально-исторических, экономико-политических процессов в России нашего времени. Одновременно в романах содержится своеобразный призыв, чтобы вспомнить, например, слова Сергея Викулова, представителя «деревенской лирики»: «Я хотел бы Россия, чтоб ты не забыла, что когда-то ты вся началась с деревень» [Лагуновский, online]. Можно утверждать, что сегодня, когда правит городская культура, когда традиционные национальные ценности утрачиваются, литературные произведения, посвященные теме деревни и людей живущих на земле, приобретают особую значимость.

\section{Литература}

Аристов Д., 2012, Кониепчия героического в прозе Захара Прилепина (роман «Патологии»), «Известия Уральского федерального университета», № 2 (102), Екатеринбург, с. 26-36, [online], http://elar.urfu.ru/bitstream/10995 /21161/1/iurg-2012-102-03.pdf, [12.07.2014].

Аристов Д., 2011, О природе реализма в современной русской прозе о войне (2000-е годы), «Вестник Пермского университета», вып. 2 (14), с. 169 -175, [online], http://www.rfp.psu.ru/archive/2.2011/aristov.pdf, [13.02.2014].

Ахмедова М., 2013, «По мне не будут причитать». Интервью с Захаром Прилепиныл, «Эксперт Online», от 9 июля, [online], http://expert.ru/2013/ 07/9/po-mne-ne-budut-prichitat/?n=66995, [28.10.2014].

Бабаян О., «Город делает людей слабее». Интервъю с Романом Сенчиным, [online], http://www.hrono.ru/proekty/parus/sench0311.php, [23.10.2014].

Бабицкая В., Роман Сенчин. Елтьишевь (речензия), [online], http://os.colta.ru/ literature/events/details/13741/?expand=yes, [20.08.2014]. 
Басинский П., 2006, Новый Горький явился, «Российская газета», № 21, от 15 мая, [online], http://www.rg.ru/2006/05/15/sanjka.html, [28.06.2014].

Беляков С., 2006, Заговор обреченных, или Захар Прилепин как зеркало несостоявшейся русской революиии, «Новый мир», № 10, [online], http://magazines.russ.ru/novyi_mi/2006/10/be15-pr.html, [21.05.2014].

Беляков С., Истоки и смылл «нового реализма»: $\kappa$ литературной ситуаиии нулевьъ, [online], http://www.rospisatel.ru/konferenzija/beljakov.htm, [06. $01.2014]$.

Беляков С., 2009, Призрак титулярного советника, «Новый мир», № 1, [online], http://magazines.russ.ru/novyi_mi/2009/1/be14.html, [14.09.2014].

Беляков С., 2009, Прокруст любил формат, «Знамя», № 11, [online], http://magazines.russ.ru/znamia/2009/11/be15.html, [09.10.2014].

Беляков С., 2011, Роман Сенчин: неоконченньй портрет в сумерках, «Урал», № 10, [online], http://uraljournal.ru/work-2011-10-218, [20.08.2014].

Богатырева А., 2014, Деревня в творчестве Захара Прилепина (на материале романа «Санькя» и сборника рассказов «Ботинки, полные горячей водкой»), «Вестник Воронежского государственного университета», № 3, c. 9-13, [online], http://jour.vsu.ru/edition/journals/vestnik_filology/2014_ vestnik.pdf, [01.10.2014].

Бойко М., 2008, Лаконичность, а не доскональность, «НГ Ex Libris», от 11 сентября, [online], http://www.ng.ru/ng_exlibris/2008-09-11/6_karasev.html, [16.10.2014].

Ганиева А., 2010, Серьм по серому, «Вопросы литературы», № 3, [online], http://magazines.russ.ru/voplit/2010/3/ga9-pr.html, [20.08.2014].

Гликман К., 2011, Новый, талантливый, но.. Захар Прилепин, «Вопросы литературы», № 2, [online], http://magazines.russ.ru/voplit/2011/2/g17pr.html, [28.06.2014].

Журов А., 2012, Самописеи падения, «Новый мир», № 6, [online], http://magazines.russ.ru/novyi_mi/2012/6/zh17-pr.html, [07.09.2014].

Захар Прилепин - Omзьъвь, [online], http://zaharprilepin.ru/ru/otzyvy, [25.04. 2015].

Иванова И., 2013, Деревенская проза в современной отечественной литературе: конеи мифа или перезагрузка?, «Грамота», № 6 (24), ч. I, с. 88-94, [online], http://scjournal.ru/articles/issn_1997-2911_2013_6-1_23.pdf, [21.08. $2014]$.

Калинин А., Деревня «Караул!», [online], http://syktyvkar.eparchia.ru/nlk95. html, [26.08.2014].

Комаров К., 2011, Цена честности, «Урал», № 2, [online], http://uraljournal. $\mathrm{ru} /$ work-2011-2-142, [01.08.2014].

Королева С., 2009, Образ праведника в «деревенской прозе» В. Распутина ( $K$ вопросу о художественном воплощении народной религиозности), «Вестник Пермского университета», вып. 1, с. 79-89, [online], http://www.rfp.psu.ru/archive/1.2009/koroleva.pdf, [28.10.2014]. 
Костырко С., 2006, По кругу, «Новый мир», № 10, [online], http://magazines. russ.ru/novyi_mi/2006/10/ko16_pr.html, [21.05.2014].

Лагуновский А., Русская поэзия 60-80-х г2. ХX века, [online], http://stihi.ru/ 2009/07/14/4617, [24.08.2014].

Латынина А., 2007, «Вижу сплошное счастье...», «Новый мир», № 12, [online], http://magazines.russ.ru/novyi_mi/2007/12/la11-pr.html, [21.05.2014].

Лебёдушкина О., 2006, Реалисты-романтики, «Дружба народов», № 11, [online], http://magazines.russ.ru/druzhba/2006/11/le13-pr.html, [16.09.2014].

Липовецкий М., «Реализм в русской литературе - это фантом», [online], http://litlive.ru/topics/digest/viewpost/396, [28.12.2015].

Маркова Д., 2010, Роман Сенчин. Елтышевы. В отсутствие неба над головой, «Знамя», № 10, [online], http://magazines.russ.ru/znamia/2010/10/ma 21-pr.html, [01.08.2014].

Муравьев М., «Консерватизм входит в жесточайшее противоречие с либерализмом как таковым». Интервью с Захаром Прилепиньм, [online], https://www.facebook.com/zprilepin/posts/391187627618844, [26.08.2014].

Наринская А., 2006, Начбол в России больше, чем нацбол, «Коммерсанть», № 222, от 28 ноября, [online], http://www.kommersant.ru/doc/725564, [16.09.2014].

Николаев Н., Воробьева Е., 2013, З. Прилепин в контексте традичии литературного осмыслления «русского бунта», «Дискуссия», № 4 (34), [online], http://www.journal-discussion.ru/publication.php?id=141, [25.08.2014].

Новиков Д., 2007, Поморские сказы имени Шотмана, или Мифы нового реализма, «Вопросы литературы», № 4, [online], http://magazines.russ.ru/ voplit/2007/4/no14-pr.html, [16.09.2014].

Осс Н., 2010, Пессимистический реалист. Интервью с Романом Сенчиным, «Известия», от 16 ноября, [online], http://izvestia.ru/news/368126, [22.08. 2014].

Пирогов Л., 2009, Мертвые души и доктор Сенчин, «Литературная газета», № 45 (6249), от 11 ноября, [online], http://old.lgz.ru/article/10732, [22. 08.2014].

Погорелая Е., 2009, ...На севших батарейках?.., «Знамя», № 10, [online], http://magazines.russ.ru/znamia/2009/10/po20-pr.html, [21.08.2014].

Прилепин 3., «Если слушать писателей, все развалится». Интервью с Романом Сенчиныл, [online], http://www.zaharprilepin.ru/ru/litprocess/inter vju-o-literature/roman-senchin-esli-slushat-pisatelei-vse-razvalitsya.html, [14.09.2014].

Прилепин 3., 2006, Санькя, Москва, [online], http://loveread.ws/read_book.php?id $=11951 \& p=7$, http://loveread.ws/read_book.php?id $=11951 \& p=8$, http://loveread.ws/read_book.php?id $=11951 \& p=20$, http://loveread.ws/read_book.php?id $=11951 \& p=21$, http://loveread.ws/read_book.php?id=11951\&p=22, 
http://loveread.ws/read_book.php?id $=11951 \& \mathrm{p}=23$, http://loveread.ws/read_book.php?id $=11951 \& p=68$, http://loveread.ws/read_book.php?id=11951\&p=69, [15.09.2014].

Прилепин 3., 2009, Ваше императорское величество, [в:] Terra Tartarara. Это касается лично меня, Москва, [online], http://loveread.ws/read_book.php? $\mathrm{id}=11944 \& \mathrm{p}=44,[01.10 .2014]$.

Прохорова Т., 2013, Формь проявления национальной идентичности в романе Захара Прилепина «Санькя», «Филология и Культура», № 2 (32), c. 196-199, [online], http://philology-and-culture.kpfu.ru/?q=system/files/ 43_4.pdf, [28.06.2014].

Пустовая В., 2009, Иск маленькому человеку, «Новый мир», № 12, [online], http://magazines.russ.ru/novyi_mi/2009/12/pu13-pr.html, [29.08.2014].

Пустовая В., 2009, Матрица бунта, «Континент», № 140, [online], http://magazines.russ.ru/continent/2009/140/pu23-pr.html, [07.01.2014].

Пустовая В., 2005, Пораженцы и преображенцы. О двух актуальньх взглядах на реализм, «Октябрь», № 5, [online], http://magazines.russ.ru/october/ 2005/5/pust18.html, [25.10.2014].

Роднянская И., 2010, Род Атридов, «Вопросы литературы», № 3, [online], http://magazines.russ.ru/voplit/2010/3/ro12-pr.html, [29.08.2014].

Ротай Е., 2012, Константы художественного мира в повестях Р. Сенчина, «Научный журнал КубГАУ», № 77 (03), [online], http://ej.kubagro.ru/ 2012/03/pdf/36.pdf, [30.08.2014].

Ротай Е., 2013, «Новый реализм» в современной русской прозе: художественное мировоззрение Р. Сенчина, 3. Прилепина, С. Шаргунова. Автореферат диссертации на соискание ученой степени кандидата филологических наук, Краснодар, [online], http://www.kubsu.ru/Science/dissertation/ avtoref/2013/ROTAYEM.doc, [28.07.2014].

Рудалев А., Беляков С., 2009, Феноменология Прилепина, «Литературная Россия», № 23, [online], http://litrossia.ru/2009/23/04177.html, [28.06.2014].

Русаков Э., 2013, «Не бойтесь писать правду...». Интервью с Романом Сенчинылм, «Красноярский рабочий», от 12 сентября, [online], http://www. krasrab.com/archive/2013/09/12/36/view_article, [08.09.2014].

Сафронова Е., 2010, Роман о стычке города и деревни. Интервью с Романом Сенчиньлм, «Рязанские ведомости», № 210 (3761), от 4 ноября, [online], http://rv-ryazan.ru/news/5250.html, [19.10.2014].

Сенчин Р., 1997, Вдохновение, «Октябрь», № 12, [online], http://magazines. russ.ru/october/1997/12/senchin-pr.html, [06.09.2014].

Сенчин Р., 2004, Вперед и вверх на севших батарейках, «Новый мир», № 4, [online], http://magazines.russ.ru/novyi_mi/2004/4/snchin2-pr.html, [30.08. $2014]$.

Сенчин Р., 2009, Eлтьишевьи, «Дружба народов», № 3, № 4, [online], http://magazines.russ.ru/druzhba/2009/3/se14-pr.html, http://magazines.russ.ru/druzhba/2009/4/se28-pr.html, [12.07.2014]. 
Сенчин Р., 2001, Минус, «Знамя», № 8, [online], http://magazines.russ.ru/znamia/2001/8/sen-pr.html, [29.08.2014].

Сенчин Р., 2002, Нубук, «Новый мир», № 11, № 12, [online], http://magazines.russ.ru/novyi_mi/2002/11/sench-pr.html, http://magazines.russ.ru/novyi_mi/2002/12/senchin-pr.html, [19.08.2014].

Славина А., 2012, Философская проблематика в творчестве 3. Прилепина, [в:] Современнье подходы $к$ изучению и преподаванию русской литературьи и журналистики XX-XXI веков. Материаль XVII шешуковских чтений, Москва, с. 63-66.

Слепаков С., 2012, Вьимиание мальгх городов и деревень в России: «огораживание» XXI века?, «Альтернативы», № 3, [online], http://www.intelros. $\mathrm{ru} /$ readroom/alternativi/a3-2012/16623-vymiranie-malyh-gorodov-i-dereve n-v-rossii-ogorazhivanie-xxi-veka.html, [15.09.2014].

Современные писатели России. Библиографический указатель, сост. И. Трофимова, 2013, вып. 3, Благовещенск, с. 13-20, [online], http://www.liba mur.ru/sites/libamur/files/sovremennye_pisateli_rossii_vyp._3.pdf, [29.08.2014].

Штейнбах К., Юкио Мисима и Захар Прилепин, [online], http://www.hrono.ru/proekty/parus/stein0511.php, [12.07.2014].

Яблонская М., 2014, Захар Прилепин: Мы все время в кого-то влюбляемся», «Городские новости», № 2959, от 17 апреля, Красноярск, [online], http://gornovosti.ru/tema/interview/zakhar-prilepin-my-vse-vremya-v-kogo -to-vlyublyayemsya53627.htm, [31.05.2014].

THE WORLD OF A DYING RUSSIAN VILLAGE IN "NEW REALISTS"” LITERARY PRODUCTION (BASED ON THE NOVELS:

SANKYA BY ZAKHAR PRILEPIN AND THE YELTYSHEVS BY ROMAN SENCHIN)

\section{S U M M A R Y}

Two novels of two prominent representatives of the "new realism" are the subject of an analysis in this article. There are Sankya (2006) by Zakhar Prilepin and The Yeltyshevs (2009) by Roman Senchin. The article deals with the problem of the degradation of the contemporary Russian village (at the beginning of the $21^{\text {st }}$ century). The village disintegrates under the new economic conditions. Sankya about a young rebel is devoted to the theme of the individual's rights to action against a hostile and unjust society, against the new capitalistic rules. Senchin's story portrays the demise of the ordinary Russian family that moves to the village. Living in the village, the family sinks into alcoholism and violence. In his novel Senchin shows Russian's path to a dead-end, to life devoid of any spirituality.

Ewa Pańkowska e-mail: ela.pankowska@poczta.onet.pl 